\title{
Momentum, October 2002
}

Population Council

Follow this and additional works at: https://knowledgecommons.popcouncil.org/ series_newsletters_momentum How does access to this work benefit you? Let us know!

\section{Recommended Citation}

"Momentum, October 2002," newsletter. New York: Population Council. 


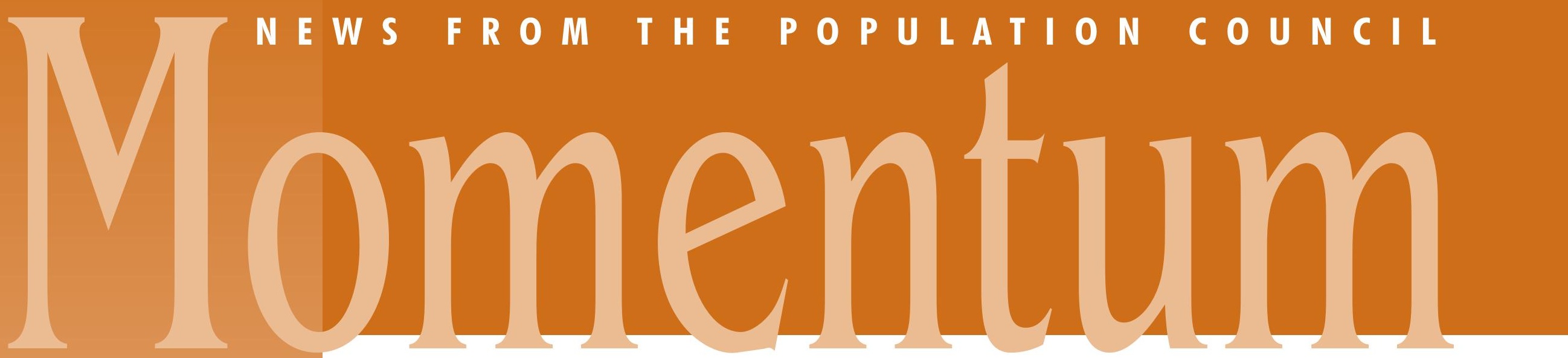

I N S I DE

OCTOBER 2002

Dendritic cells and HIV

Emergency

contraception

XIV International AIDS Conference

Succession planning for HIV-positive parents 3

Girls' soccer program breaks down gender barriers ...... 4

\section{U.S. Senator}

Rockefeller speech... 4

Council people ..... 6

Population

scientists elected.... 7

USAID renews

Horizons

7

Responding to

Cairo

\section{Population Council takes a leading role in emerging AIDS-prevention arena}

Over the past decade, the Population Council's comprehensive microbicide program has earned the Council distinction as a leader in the field of microbicide development. Its most promising product, Carraguard ${ }^{\mathrm{TM}}$, will be among the first microbicide candidates to enter a large-scale effectiveness trial.

Formulated as gels or creams, microbicides, if proven effective, could be used in the vagina or rectum to provide protection from HIV and other sexually transmitted infections (STIs). Microbicides offer a potentially powerful new approach to addressing the global HIV/AIDS pandemic. For this reason, they have become a priority for the Council's biomedical, public health, and social scientists, and for dozens of other organizations working in HIV prevention.

Globally, the prevalence of HIV among women is growing more rapidly than among men. This trend in the HIV/AIDS epidemic is driven by social, cultural, and economic conditions that limit women's ability to protect themselves from infection. In developing countries, women can be especially vulnerable because existing strategies for HIV prevention-mutual monogamy among HIV-negative partners, condom use, and treatment of STIs-are not practical for many of them. Because of an urgent need for a means of prevention that women can control, the Council is developing a vaginal microbicide. Carraguard, which is believed to be noncontraceptive, may allow women to become pregnant, a desirable feature for women who wish to protect themselves from HIV infection but not necessarily to avoid pregnancy.

\section{Product development}

Since 1986, scientists at the Council have been exploring how HIV is sexually transmitted. After discovering that HIV-

infected cells from semen could infect cells lining the vagina and cervix, scientists conducted laboratory studies to test the efficacy of substances to prevent infection. Compounds called sulfated polysaccharides proved especially promising. Among the sulfated polysaccharides tested, carrageenan was the most successful in preventing infection by similar viruses in mice.

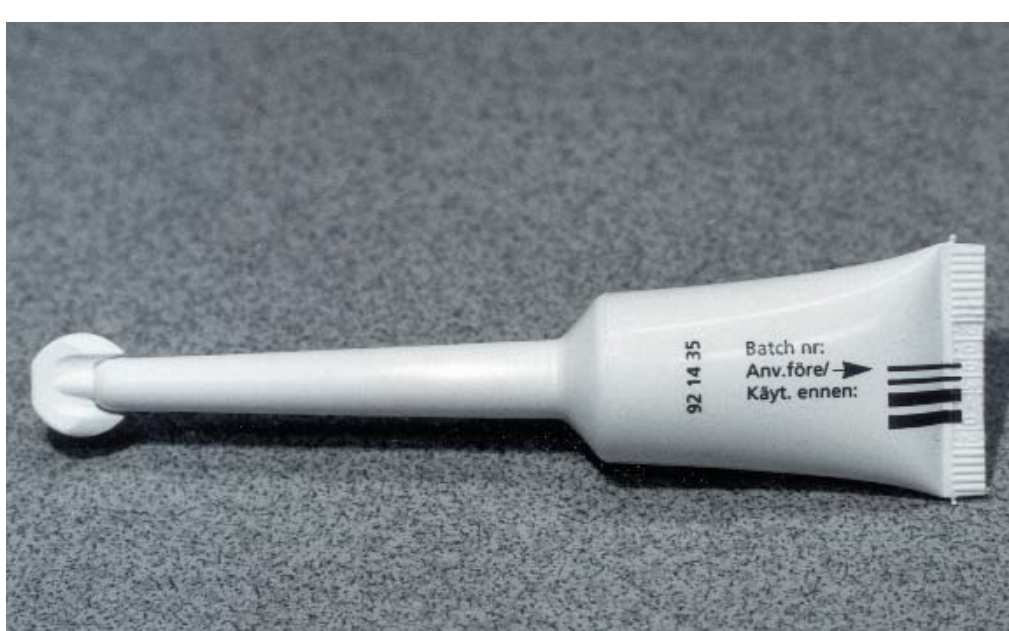

Applicator, used in microbicide clinical trial, delivers a single dose of gel.

Derived from seaweed, carrageenan has long been recognized as nontoxic and stable, even when exposed to extreme temperatures. Inexpensive and abundant, it has been used for decades as a thickener in foods and as an emulsifier in creams and lotions. Although the U.S. Food and Drug Administration had already approved carrageenan as a food additive, Council staff are conducting in-depth preclinical and clinical evaluations necessary to secure its approval as a new active pharmaceutical ingredient. The formulation, Carraguard, appears to be safe and nonirritating, and laboratory studies have indicated its effectiveness against HIV and the herpes simplex virus 2.

\section{clinical testing}

In the growing microbicide field, nearly 60 microbicide candidates are now in various stages of development by other organizations, with several products undergoing clinical trials. Carraguard is in the forefront, having completed early trials that tested safety and acceptability. Starting in 1996, trials of carrageenan-based microbicides for vaginal use were carried out among healthy, HIV-negative women in six countries,

continued on page 2

\section{Donors are vital component in microbicide research}

Developing a new pharmaceutical product requires a considerable investment of both time and money. In 200I, the Tufts Center for the Study of Drug Development estimated that the average cost of researching, developing, and bringing a new drug to market was $\$ 802$ million.

The microbicide field has not attracted any large pharmaceutical companies to take the initiative and invest the necessary resources. So the research and development burden has fallen on the shoulders of governmental, nongovernmental, and academic organizations, and small biotechnology firms, which have led the efforts to produce successful microbicides. Critical to their work is the support of the governments, foundations, corporations, and individuals who recognize the potential that microbicides offer in the battle against HIV and AIDS.

Significant funding from the public and private sectors has expedited progress in the Population
Council's microbicide program. With this funding, the Council is continuing to test its lead candidate microbicide, Carraguard (see story above), and develop second-generation candidate microbicides.

The U.S. Agency for International Development (USAID) has provided financial support for Council microbicide research for nearly a decade. Funding from the Andrew W. Mellon Foundation helped identify carrageenan for use as a candidate microbicide. Other funders that have played a key role are CONRAD, the United Kingdom Department for International Development, the Parthenon Trust, the Swedish International Development Cooperation Agency, the Hewlett and Rockefeller foundations, and especially the National Institutes of Health. Most recently, in November 200I, the U.S. National Institute of Child Health and Human Development (NICHD) awarded the Population Council a grant of
$\$ 6.8$ million aimed at developing new microbicide candidates.

In February 2002, the Bill \& Melinda Gates Foundation provided a $\$ 20$ million grant to support advanced clinical trials of Carraguard. This donation will provide a substantial part of the funding needed for the large-scale study of 6,000 women in southern Africa. This is the third Gates Foundation grant assisting the Council's microbicide research.

David M. Phillips, the principal investigator and director of the Council's biomedical research on microbicides, notes, "As we increase our understanding of the mechanisms of sexual transmission of HIV and other pathogens, we gain insight into new approaches for developing a microbicide that will be more efficacious against HIV and be effective against a broader spectrum of other sexually transmitted pathogens." 
Research on

dendritic cells

may hold the key

to microbicide and HIV vaccine development

Melissa Pope, an immunologist at the Population Council's Center for Biomedical Research, is conducting research on dendritic cells that may point the way toward the development of effective HIV vaccines and microbicides (see story page I). Dendritic cells, positioned within mucous membranes throughout the body, are among the first white blood cells that encounter HIV following sexual or mother-to-child infection.

Pope, who joined the Council from Rockefeller University last October, has contributed to one of the major accepted theories for the mechanism of sexual transmission of HIV. Her research on the role of dendritic cells in HIV infection has earned recognition from numerous organizations, including, in February 2002, a prestigious award from the Elizabeth Glaser Pediatric AIDS Foundation.

The award honors Pope's research on strategies to enhance dendritic cell function to boost oral vaccine efficiency, a vital step in preventing infection with HIV and other pathogens in children. Her work is also supported by the Rockefeller Foundation and the National

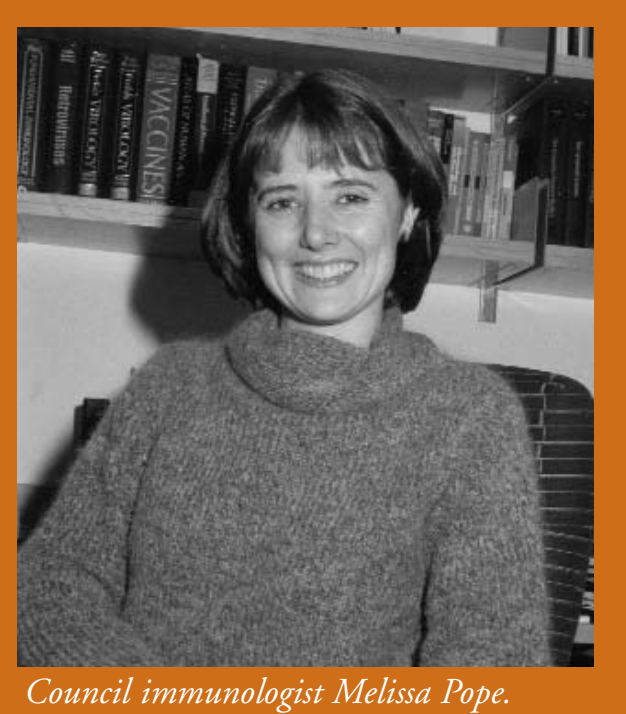

Institutes of Health, which has provided funding of research on nextgeneration microbicides that allows Pope to evaluate how the formulations under investigation could influence dendritic cells in ways that may reduce the transmission of HIV.

"We still have a lot to learn about the interactions between HIV, dendritic cells, and other immune cells," Pope said. "But this basic research-mapping out these microscopic cellular activities-lays the groundwork for the development of products that may one day save people's lives." microbicide program

continued from page 1

including the United States. Overall, the women reported that the gel was easy to use and did not cause significant irritation.

The Council then conducted safety and acceptability trials in South Africa and Thailand among 565 healthy,

HIV-negative, nonpregnant women. The trials were implemented by the University of Cape Town, the Medical University of Southern Africa, and the Thailand Ministry of Public Health-U.S. Centers for Disease Control and Prevention Collaboration. Women were instructed to apply the gel at least three times a week and before each act of vaginal sexual intercourse. Women in the trial received safer-sex counseling and monthly gynecological exams, with testing and treatment of curable STIs. All trial participants were given condoms and encouraged to use them.

A larger-scale trial is now planned to determine Carraguard's effectiveness in averting HIV infection and other STIs. The trial must be conducted in locations with at least three percent annual HIV incidence to determine whether the product prevents infection. The trial will be carried out with 6,000 HIV-negative women at four sites in Botswana and South Africa. All women will be followed for two years. The trial is projected to begin in 2003, with results expected in 2007.

\section{Does easy accessibility of emergency contraception increase sexual risk-taking?}

Proper use of emergency contraception could prevent 1.7 million of the three million unintended pregnancies that occur every year in the United States. Women who have intercourse without contraception, experience contraceptive failure, or are victims of rape have two options to reduce their chances of pregnancy. Collectively known as emergency contraception, these treatments include taking high doses of birth control pills or having an intrauterine contraceptive device inserted. Emergency contraception has been known in the medical community for decades, but only recently has this information come to the attention of the general public, among whom greater awareness could make a dramatic difference.

Emergency contraceptive pills are regular birth control pills, such as $\mathrm{Ovral}^{\circledR}$ or Ogestrel $^{\circledR}$, taken in higher doses than usual, or pills developed specifically for emergency contraceptive use. Preven ${ }^{\circledR}$, which has been on the market since 1998 , and Plan $\mathrm{B}^{\circledR}$, available since 1999 , are the two emergency contraceptive products available in the United States. If the first dose of emergency contraceptive pills is taken within 72 hours of unprotected sex, followed by a second dose 12 hours later, the treatment will be effective in preventing pregnancy for at least 75 percent of the women who otherwise would have become pregnant. Taken within 24 hours of unprotected sex, the pills' ability to interrupt ovulation, fertilization, or implantation of the egg increases significantly.

The second method of emergency contraception is the insertion of an intrauterine device within seven days after unprotected intercourse. This procedure reduces the probability of pregnancy among 99 percent of the women who would have become pregnant without treatment. Cramping and bleeding are the most frequently noted side effects.

Although millions of women worldwide have used emergency contraception, it is not as effective in preventing pregnancy as regular birth control methods. It is, as the name states, for emergencies. But emergency contraception does offer a safe way to reduce unintended pregnancy and, consequently, to reduce reliance on induced abortions. As part of its global portfolio of activities to improve women's reproductive health, the Population Council staff has conducted research to improve awareness of and access to emergency contraception.

In most countries a prescription is needed to obtain emergency contraception pills, but making emergency contraception accessible without a prescription would reduce the traceptive more useful for the emergencies for which it is intended. Long shown to be a safe method, the pill's only side effects are nausea and vomiting. However, there is some with, or abandon, their current family planning methods.

Population Council researchers asked, "What would dence of unprotected sex would be higher if women had bers conducted a study among 411 women from a family planning clinic in Pune, India. After agreeing to be part of the study, participants were either provided information on given three courses of the prescribed treatment for use if needed, in addition to instructions.

The study results showed that women who received both information and pills were not significantly more mation only. But women with supplies were nearly two times as likely to use emergency contraception pills after one in the group used the pills more than once during the 12-month study, demonstrating that most women will not emergency contraception. The vast majority of the women cians need not explain the rules immediately before use. Interestingly, one-quarter of those who received pills and had unprotected sex during the study period did not use them. Researchers attributed this phenomenon to the study groups' lack of familiarity with this method. Participants who had pills on hand liked having them available, but those who did not receive pills were unanimous in saying that they wished they had had them.

This study, in combination with other Population Council efforts to examine the use and delivery of emergency contraception, is an important source of sciencebased on research, rather than ideology, to better serve their female constituents. visit http://ec.princeton.edu/questions/index.html. working with the community and women's health advocates

While biomedical scientists have worked to develop effective and safe microbicides, public health and social scientists at the Council have worked closely with women's health advocates and activists to ensure that the ethical and practical challenges of testing and introducing microbicides are taken into consideration. The Council has organized meetings in Thailand and South Africa with public health officials, advocates, and researchers to discuss the trials. In Thailand, the Chiang Rai Community Advisory Group met regularly throughout the safety and acceptability trial to help ensure that the research responded to the needs of the local community. The group will serve as a model for community advisory groups for the effectiveness trial in southern Africa.

\section{Looking ahead}

As the Carraguard trials progress, Population Council scientists continue to conduct basic research on HIV transmission and to work on developing second-generation microbicides that may be more effective against a broader range of sexually transmitted infections and have contraceptive properties. Council researchers are also conducting safety trials of Carraguard in HIV-positive women and men and are planning safety studies on rectal use of the candidate microbicide.

effort, time, and, in cases where a doctor's fee is involved, cost associated with procuring the pills, making this type of confear that ease of access may encourage women to take chances happen if women were provided with pills during a routine doctor's visit, given instructions, and asked to store the pills for use in an emergency?" To assess whether or not the incisuch access to emergency contraception, Council staff memhow to use and where to obtain emergency contraceptives or likely to have unprotected sex than women receiving inforunprotected intercourse as the other study participants. No abandon their regular family planning methods in favor of who used the regime did so properly, indicating that physibased information to help policymakers formulate choices

For further information about emergency contraception, 


\section{The Population Council at the XIV International AIDS Conference in Barcelona}

The XIV International AIDS Conference, held in Barcelona from July 7 to 12,2002 , brought together more than 17,000 of the world's top scientists, community leaders, policymakers, and people living with HIV. The largest and most important of the international meetings devoted to AIDS, this conference, occurring every two years, provides the worldwide AIDS community with a forum to discuss all aspects of the epidemic, including scientific research, policy, and community action. Conference participants exchange information, make the case for increased AIDS spending, and discuss how to mobilize communities and governments to respond to the crisis.

"The conference is a culmination of what is happening in the AIDS field," said Naomi Rutenberg, senior program associate with the Council's Horizons program, a USAID-funded project carried out by the Population Council and several other organizations. "It is important for building networks and consensus on how to move forward."

The Population Council, one of the conference's 25 "supporting institutions," contributed on many levels to this year's wide-ranging program. Andrew Fisher, the director of the Council's Horizons program; Samuel Kalibala, a program associate at the Council's office in Kenya; and Purnim Mane, a Council vice president and director of its International Programs Division, were involved in the planning of the conference. Council staff members and collaborators presented the latest findings on the organization's

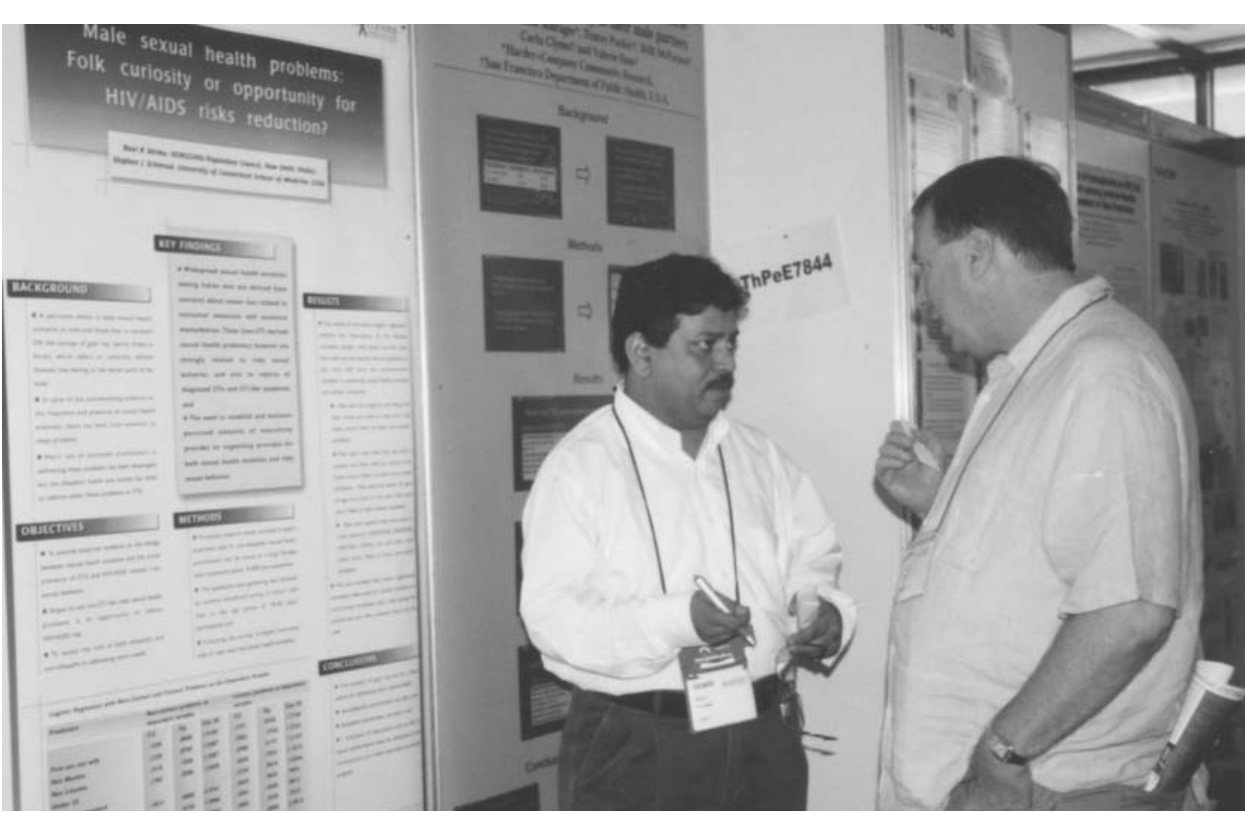

Council researcher Ravi Verma (left) discusses his recent study with a conference participant during a poster session.
AIDS-related research at more than 80 technical sessions. They hosted two satellite meetings, one on the Microbicides Basic Science Network and another titled "Evaluating the Economics of HIV/AIDS Inter-

ventions."

Laelia Zoe Gilborn of the Council's Horizons program, who also served as a rapporteur for conference sessions on interventions and program implementation, described a pro-

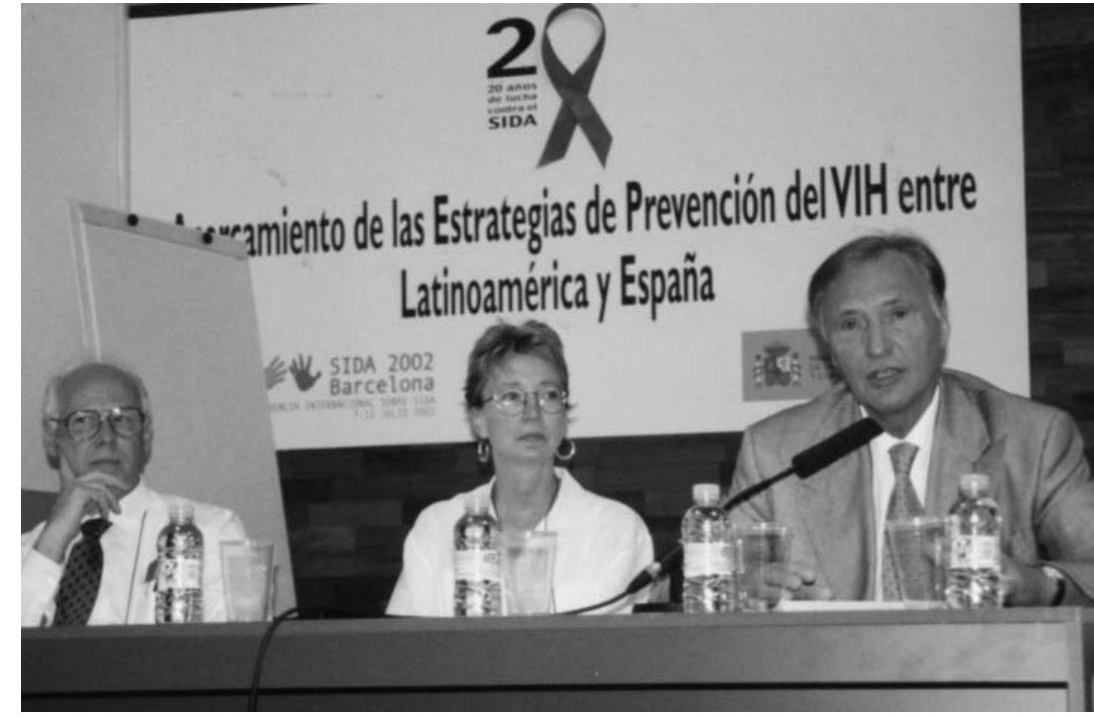

left to right: the Council's David Phillips, Robin Maguire, and Elof Johansson welcome guests to the Microbicides Basic Science Network meeting.

children's futures. Naomi Rutenberg discussed issues related to mother-tochild transmission of HIV and the perception among adolescents in South Africa of their risks of contracting the disease. Horizons collaborator Ann McCauley (International Center for Research on Women) reported on how school programs could increase condom use, citing successful programs in Mexico and Thailand.

The Population Council's work on microbicides was the topic of several presentations and scientific posters. Council scientists David Phillips and Melissa Pope presented their research at the meeting on the Microbicides Basic Science Network, a group of organizations that focuses on developing HIV-prevention technologies.

The Council's participation in the biennial international AIDS conference is an important way to disseminate its research to scientists, policymakers, community leaders, and people living with HIV. In addition to information provided during oral presentations and poster sessions, hundreds of publications and 3,500 CD-ROMs on the Council's HIV/AIDS work were distributed to more than 4,000 visitors during the six-day conference.

For a full listing of the Population Council's activities at the International AIDS Conference, visit www.popcouncil.org/mediacenter/ barcelona/index.html. $\square$

\section{Helping HIV-positive parents plan for their children's futures}

Population Council researcher Laelia Zoe Gilborn testified before the U.S. House of Representatives International Relations Committee in April 2002 on the urgent need to create programs for HIVpositive parents to help them plan for their children's future well-being. "A wide body of literature tells us that children affected by AIDS are vulnerable in almost all aspects of their lives," said Gilborn, a staff program associate of the Council's Horizons program, which aims to improve HIV/AIDS prevention, care, support, and treatment services in developing countries. "Efforts that prolong the lives of parents and help them prepare for their children's future can help the entire community by elevating the well-being of vulnerable children."

More than 1.7 million children in Uganda have been orphaned by the AIDS epidemic; throughout sub-Saharan Africa, that number soars to 13.2 million. In the year 2000, the Uganda AIDS Commission surveyed sources of outside assistance for orphans and vulnerable children and found that only five percent of AIDS-affected children receive support from assistance programs.

Gilborn and her colleagues from Makerere University in Kampala, Uganda, together with the Ugandan office of Plan International, an international nongovernmental organization that assists children and their families, designed a research project to determine whether services that begin when parents are still alive are more effective in improving the long-term well-being of children than those that respond only after parents die. The project, supported by the U.S. Agency for International Development, draws upon an approach pioneered by the National Association of Women Living with AIDS (NACWOLA) of Uganda.

"Succession planning," as the program's approach is called, helps HIV-positive parents provide for their children's futures. Components include assistance in choosing a guardian for the children, preparing a written will, acclimating children to the appointed guardian, and developing programs enabling both parents and future guardians to generate income.

A core element of the succession planning program is helping parents create "memory books" that contain photographs, family trees, anecdotes, and other important information providing tangible links to the children's pasts. These books, which many parents use to help break the news to children that they are HIV-positive, later become the children's cherished mementos. "Despite cultural taboos about discussing death," Gilborn said, "parents in the program have begun to see memory books as a way to communicate with children and to leave them with stories about their ancestors and childhoods."

Drawing on the Horizons study for her Congressional testimony, Gilborn identified priorities for community-level interventions. The first priority should be keeping HIV-positive parents alive and healthy as long as possible. Efforts should also be made to reinforce the community's ability to provide for its members. Additional support for schools, local nongovernmental organizations, and religious organizations can help the community care for its members in need. Protecting the property rights of women and children by providing legal support and education is also crucial. These efforts have already helped orphans to retain their family property and land and, in some cases, to support themselves with small gardens.

In concluding her Congressional testimony, Gilborn added a word of caution. "It is surprisingly difficult to determine which children are affected by AIDS when so few people know or reveal their HIV status. Community programs can spend valuable resources on elaborate systems to identify AIDS-affected children, only to further label them and to leave behind other vulnerable children. Programs that elevate the well-being of all vulnerable children can avoid these pitfalls and help the entire community." 


\section{A Kenyan sports association breaks down gender barriers}

An innovative youth sports association in one of Nairobi's most impoverished neighborhoods is transforming gender norms, according to a Population Council study. By challenging traditional concepts of gender-appropriate behavior while teaching girls to play soccer, the association is changing how girls think about themselves and how their communities perceive them.

The Mathare Youth Sports Association (MYSA), based in the slum of that name, is pioneering a program that teaches girls more than just soccer. It provides them with educational opportunities, access to information on HIV/AIDS, and a sense of their own abilities. In the words of one participant, "Before playing soccer, I was fearful; now I am not because I am used to mixing with people, and I know what is good and what is bad."

Sports are on the agenda of youth ministries in many countries. Although official government policies and sports organizations recognize the equal rights of boys and girls, social and cultural norms and practices often prevent girls from participating in organized sports. The Council's study notes that girls' inclusion in sports programs may be one way they can acquire the social skills and confidence they need to participate fully in their societies.
MYSA teaches the girls that they are strong and capable. Wearing the team jersey and competing on makeshift soccer fields throughout the community provide them with a public identity and status. By offering a chance for international travel to play in tournaments abroad, the program "enrolls" girls in the citizenship of the world. The name of one of the teams, "Sisters with Talent," illustrates the girls' image of themselves as strong, talented women linked by a sense of family ties.

“Through MYSA's efforts we have begun to see how sports can serve as an entry point for social development and for the transformation of gender norms," wrote Council authors Martha Brady and Arjmand Banu Khan. "Over the years MYSA has received international recognition and acclaim for its vision and reach."
MYSA began as a club for boys kicking balls made of plastic bags and twine around the garbage dumps in Mathare. The notion of broadening MYSA to include girls took hold a decade ago after the boys and their coaches took part in a competition for the Norway Youth Cup, one of

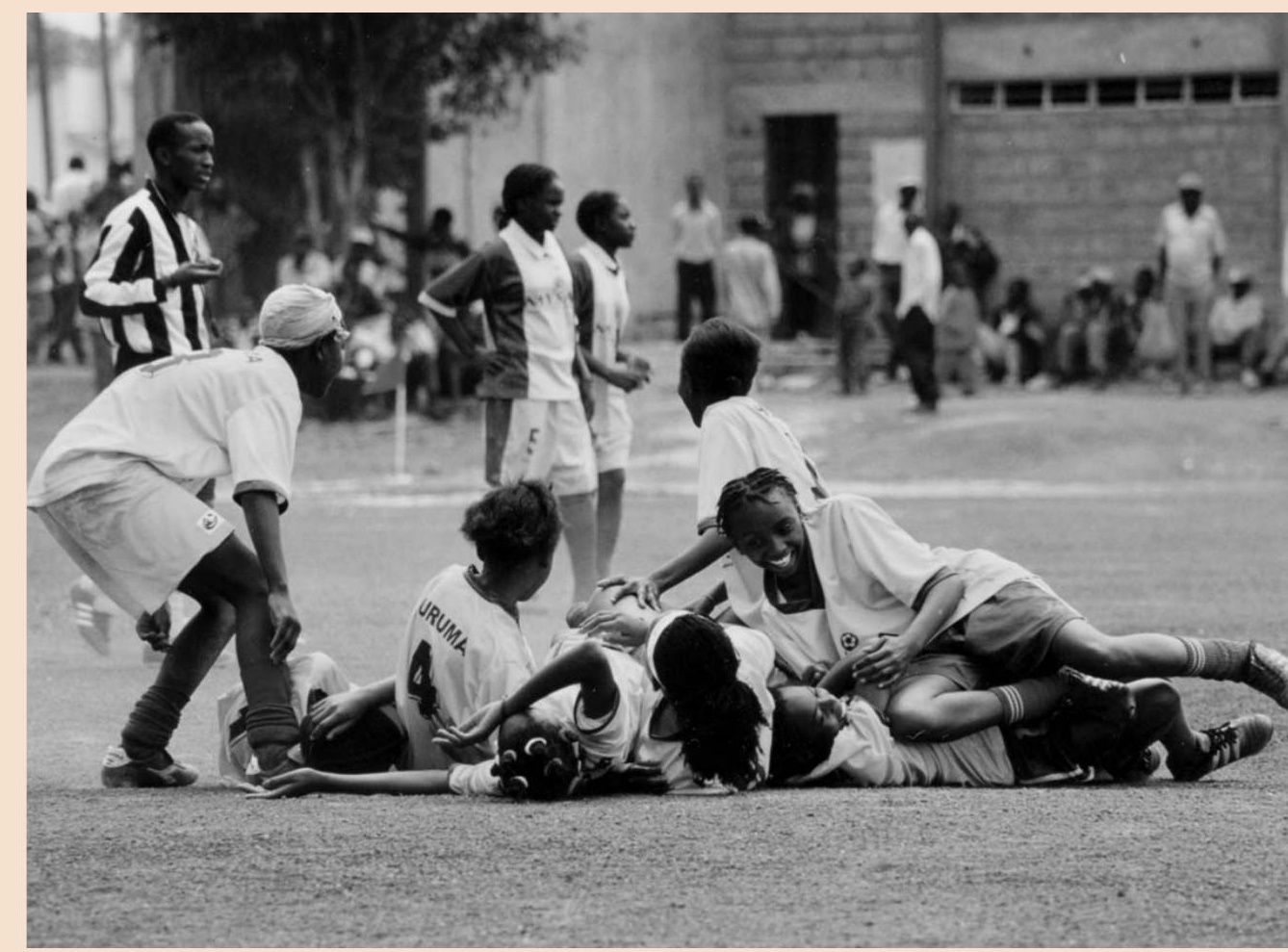

Soccer program helps build confidence and social skills for Kenyan girls.

\section{Excerpts from the speech of U.S. Senator John D. Rockefeller IV at the Population Council's 50th Anniversary Dinner, New York, June 5, 2002}

My father wanted nothing less than to change the world, and he devoted his life and his fortune to doing so . . . The Population Council, with its fight to help people choose their families and control their destinies, was my father's greatest passion.

Along with a handful of population pioneers, my father understood that accelerating population growth was a threat to the world he was working to create - a world in which every individual had a chance "to lead a life of satisfaction and purpose, to achieve in life more than mere survival." In making the connection between population and poverty as early as the 1930s, he was very much a visionary. And now, in the 21st century, when the global poverty the Population Council attacks is a source not only of moral outrage, but of crime and terror, his vision seems even more penetrating.

Today, in a world where goods and services, immigrants, workers, pollution, crime, and terro

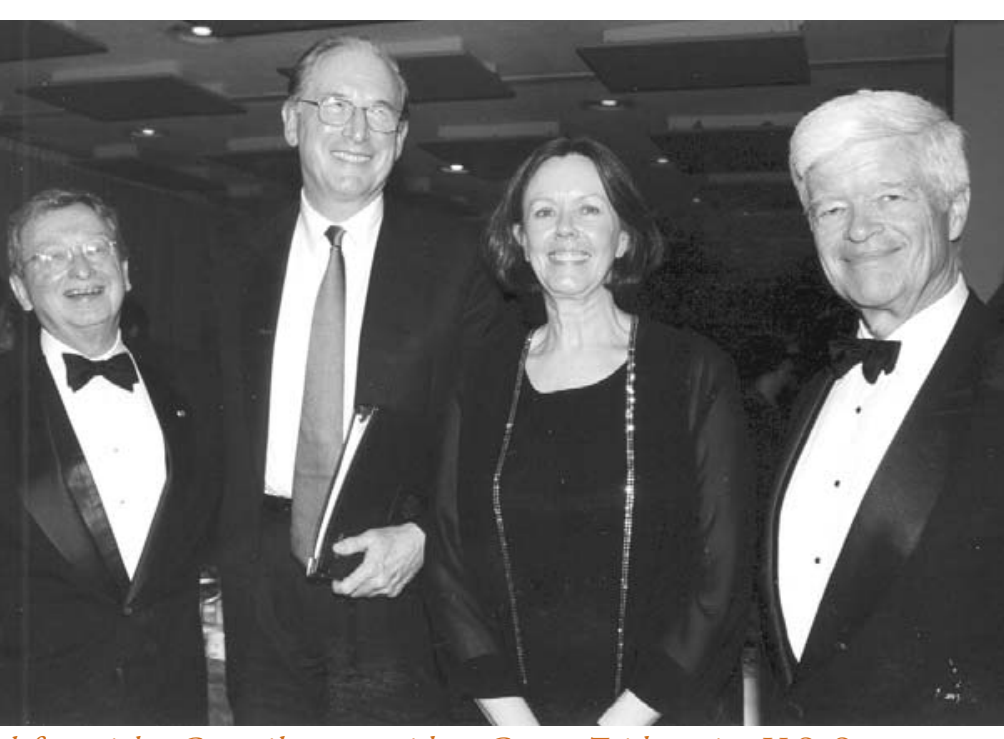

left to right: Council past president George Zeidenstein, U.S. Senator board chairman Rodney Waoner. move from nation to nation irrespective of borders, poverty is also a direct, physical threat to the American people. . . Four-fifths of the world's six billion people live in developing nations. Three billion live on less than $\$ 2$ a day. One in five human beings lives in absolute poverty - earning less in a month than it costs to park your car overnight in Manhattan.

At the same time, a global communications web beams images of American affluence and ostentation to every corner of the globe. The sharp contrast between slow or even negative growth for billions and the accelerating affluence of America and the industrialized world makes the United States even more attractive - and, for some, more abhorrent - than ever. They pay attention to us. But we don't pay attention to them. Insulated as we are from the world's worst pockets of poverty, or focused on poverty here at home, it is terribly easy for Americans to put the problem out of our minds.

It's time for us to engage the rest of the world, as human beings.

That means a foreign aid budget that reflects the magnitude of the poverty we face, based on need and effectiveness. That means an education system that teaches languages, geography, world history, and geopolitics- to kindergarteners and to graduate students. That means a U.S. diplomatic strategy based on cooperation and multilateral action, rather than impulse and naiveté. It means a commitment to public service as educators, volunteers, elected officials, and career activists. And it means a global commitment to family planning and to population services.
I know that there will never be enough support flowing from the West to less-developed nations to educate every child, support every entrepreneur, empower every individual. But family planning can help to close the gap. Large government projects are important: like power generation, new schools, and drinkable water. But when people can control the size of their families, they have a far greater ability to pull themselves up on their own.

A smaller family may mean that a child is sent to a secular school rather than to work or to a fundamentalist madrasah that turns out jihadists by the score. It may mean a cow, or a small plot of land. It may free a woman to contribute to the family income. Or it may save her life-every 60 seconds, a woman dies from the effects of pregnancy or childbirth. It may mean purchase of a loom or a taxi or a kiln, and the beginning of what we now call "microenterprise," the first steps toward economic independence.

In this, the Population Council, and my father, have shown us the way. Not because population services in themselves are a cure for poverty. But because you resolved the same intellectual challenge as an organization that we now face as a nation.

Fifty years ago, my father founded the Council in a world just beginning to understand the science of population growth and the biology and sociology behind it. Birth control was in its infancy. And the world's political and intellectual leaders had not yet generally grasped the importance of your efforts to realizing their own dreams for their people and their nations.

You changed that. You studied demographics, designed birth control, and built an intellectual consensus. It was critical, demonstrable progress. But it was only half the solution. 
the largest youth soccer tournaments in the world. Seeing talented and powerful female athletes from around the world convinced the Kenyan players that girls from Mathare could compete in an international arena.

Recruitment was slow initially. Girls were enthusiastic, but staff had to convince parents that sports were for girls as much as boys and that the girls would still have time for household chores such as cooking and caring for younger siblings. Parents also worried about girls' safety traveling to and from practices and when participating in matches outside the neighborhood.

Today nearly 3,000 girls, ages 11 to 16 , participate in MYSA and benefit from its sports and educational activities. MYSA provides school fees for some girls who have been members of the club for two years. The association insists on community service, so girls and boys carry out regular chores, such as clearing garbage from their neighborhoods. These efforts have won the association a United Nations Environment Programme award for environmental innovation. The girls have also won silver and bronze prizes at the Norway Youth Cup and even have been given a garbage collection truck to help in the neighborhood clean-up activities they carry out with the boys.
As the girls' capacities and sense of entitlement have developed, the program has evolved to keep pace. Initially chores were assigned according to gender norms - girls washed MYSA jerseys, which numbered several thousand, and boys maintained the sports equipment-but now both boys and girls launder the uniforms, and girls drive the garbage truck. Boys and girls care for younger children during game time (thus eliminating babysitting as a major reason why parents prevented girls from joining MYSA).

In the United States, sports participation has been shown to strengthen girls' resolve to delay sexual initiation and their ability to negotiate the use of contraception when they do become sexually active. No studies have been conducted in developing countries on the correlation between girls' sexual activity and involvement in sports, but girls participation in the Mathare program is having a positive effect on their sense of self-efficacy, an essential quality in girls' ability to resist coercion into unwanted sexual activity. "I have learned how to have my own principles and not be blown and tossed around by the wind," said one girl.

Many girls said that understanding about HIV and how they can protect themselves was the most important thing they learned at MYSA.
One girl, worried about the lack of AIDS awareness among her friends outside of MYSA, created an AIDS discussion group for them.

Participating in the Mathare program is expanding the girls' horizons in many ways. After two years as a member, a participant is eligible for scholarships, training in specialized skills, employment at MYSA, and practical experience in advising her peers or running projects. "Haba na haba hujaza kibaba," or "Step by step we reach the goal," is a MYSA motto that relates to both on-field activity and long-term success in life.

The authors of the study emphasize that planning for mixed-sex adolescent programs requires an understanding of the daily lives of girls and the community's perception of their roles. Gender equity should be articulated as a program goal, and community or educational services should be offered to gain parental approval for girls' participation in sports. Brady and Khan also believe there should be time for girls-only activities to ensure that boys do not inhibit girls from learning to express themselves and make decisions. "As they see girls in new roles, boys can learn about the strengths, capabilities, and contributions of girls and women, which may help to reshape their perceptions of females," wrote Brady and Khan.

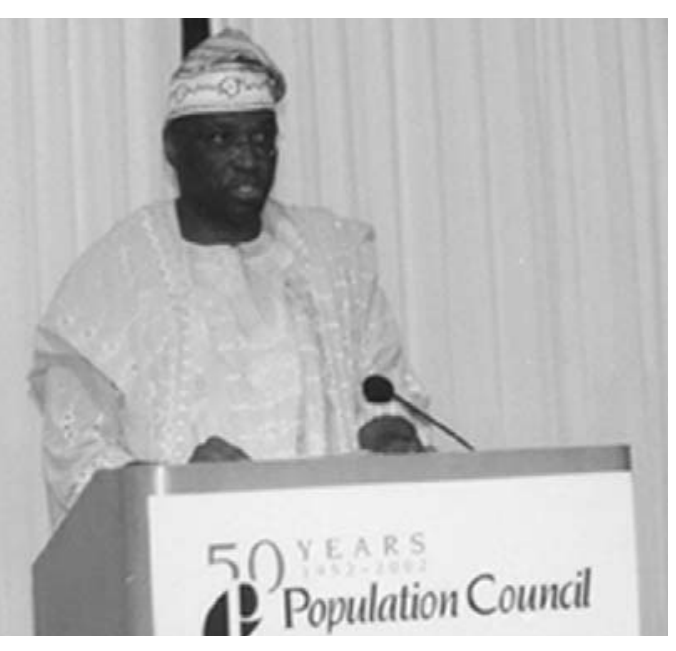

Based on his personal, decade-long association with the Population Council, Ayo Ajayi provided a moving perspective on its work in Africa.

Someone recently told me that they thought an amazing thing about my father was that he grew more open and more flexible as he grew older. I think the same is true of this organization. Because, rather than bind yourselves to an established approachvitally important, but with declining marginal utility-you began to look beyond the science until you discovered people. Guided in part by my father, the Population Council learned that empowering women, supporting families, educating individuals about their lives and their potential were important, too.

And by marrying science and bumanity, your influence and effectiveness reached the peak on which you sit today - the movement leader, active in 70 nations, and respected in political, scientific, and academic circles around the world.

If America can understand the connection between poverty and violence as well as the Population Council understands the relationship between education and overpopulation;
If we remember that people with hope will live their lives in peace, and people with economic power live in ways that benefit us all;

If we fight the war on terror by engaging in a global war on poverty, and follow your example by using politics and technology as a means while understanding that opportunity and enrichment for human beings is the only legitimate end;

Then perhaps we can find peace for America, and create a world of opportunity that, as my father wrote, "frees man to achieve his individual dignity and his full potential."

On behalf of my father's memory, myself, and all of us who share a dream of a world in which our families are safe and every person has hope, thank you. Thank you for everything you have taught us over the last 50 years; thank you for the vitally important studies and field work going on right now; and thank you for the hope you will continue to bring to people around the world for many years to come.

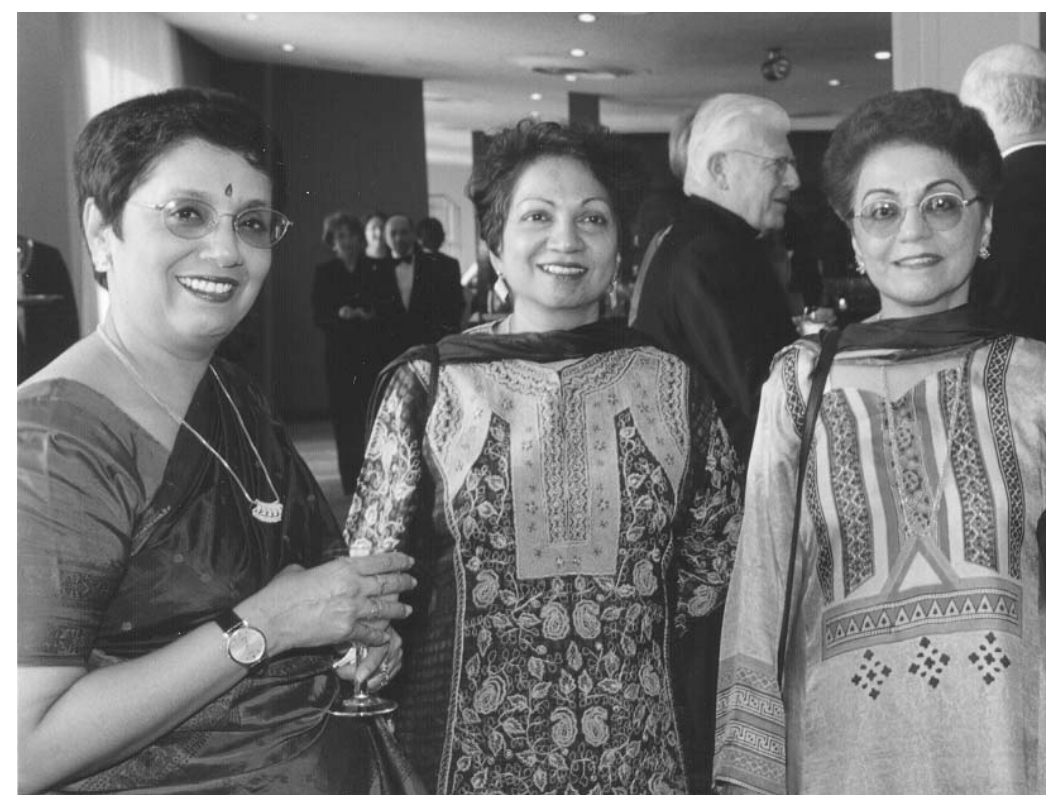

left to right: Purnima Mane, vice president, International Programs Division; Zeba Sathar, country director for Pakistan; and Fariyal Fikree, program associate, enjoy the reception before the dinner.

\section{Population Council Alumni Association}

In conjunction with the 50th anniversary celebrations, the Population Council plans to explore interest in organizing a

Population Council Alumni Association. The primary purpose of the association would be to provide a forum for social and professional activities for the Council's worldwide network of former and current staff, fellowship recipients, and members of the board of trustees. The association would be governed by a volunteer board and supported by the Population Council Development Office. If there is sufficient interest, the Council would plan several preliminary events during the coming year to bring together interested "alumni" and members of the Population Council community.

Those who would like to participate in a Population Council Alumni Association should forward their names, addresses, telephone and fax numbers, and e-mail addresses to:

Ruth Kalla Ungerer

Director of Development

Population Council

One Dag Hammarskjold Plaza

New York, NY 10017

2।2-339-05। 5

rungerer@popcouncil.org 


\section{Zeba Sathar appointed Population Council's new country director in \\ Pakistan}

In April, Zeba Sathar, Ph.D., one of Pakistan's leading social scientists, was appointed country director to lead the Population Council's research, technical

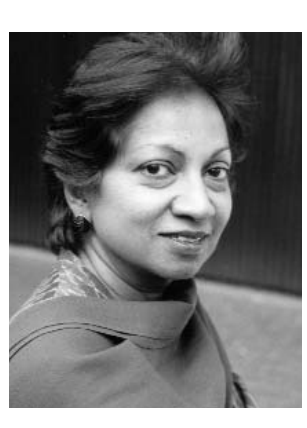
assistance, and capacity-building activities in Pakistan.

Sathar has a long history of working and collaborating with the Council. A former associate in the Council's Policy Research Division, she also received a Council Bernard Berelson Fellowship in 1992-1993 that enabled her to conduct innovative research on education and rural women's work patterns in Pakistan. In 1994, she became a program associate with the Council's International Programs Division and deputy country representative in the Islamabad office.

Her work on fertility transition and the relationship of women's education and employment to fertility has made significant contributions to the field. Sathar's professional activities include membership on many national and international boards and councils, including the governing board of the International Union for the Scientific Study of Population (IUSSP).

She received her Ph.D. in medical demography from the London School of Hygiene and Tropical Medicine. Since then, she has worked with the World Fertility Survey in London and was the Chief of Research Demography at the Pakistan Institute of Development Economics.

\section{Population Council trustee appointed UNFPA Goodwill Ambassador}

Her Royal Highness Basma bint Talal of Jordan, a trustee of the Population Council, was recently appointed a Goodwill Ambassador by the United

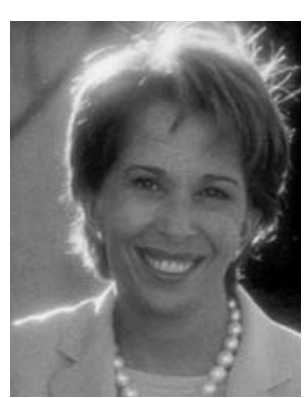
Nations Population Fund UNFPA Executive Director Thoraya Obaid hailed the appointment, saying, "Princess Basma's dedication to the health and well-being of women and children has inspired many who work in this field and

helped to improve the quality of life of women and children, not only in Jordan, but also throughout the Arab region and the world."

Princess Basma, the only sister of the late King Hussein of Jordan, has dedicated her career to some of the most pressing social issues of modern timesinternational development, gender equity, child health, and welfare. She is involved with a number of distinguished humanitarian organizations, including AWAD (the Arab Association for Women and Development) and UNIFEM (the United Nations Development Fund for Women).

Princess Basma earned a doctorate from Oxford University. Her thesis, "Contextualizing development in Jordan: The arena of donors, state, and NGOs," examined how political and economic factors have shaped Jordan's development. She currently is chairperson of the Jordanian Hashemite Fund for Human Development, which she founded at the request of the late King Hussein. She is married to Walid Al-Kurdi and is the mother of four children.

\section{ICCR member awarded France's Légion d'Honneur medal}

Philippe Bouchard, M.D., a member of the Council's International Committee for Contraception Research (ICCR), received the Chevalier dans l'Ordre

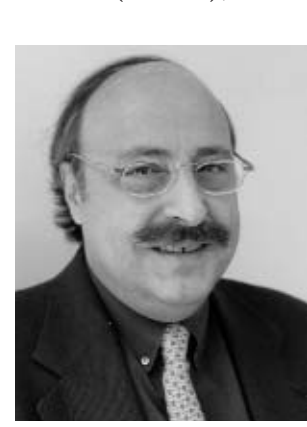
National de la Légion d'Honneur (Knight of the National Order of the Legion of Honor) in November 2001. The Légion d'Honneur, created by Napoleon Bonaparte in 1802 to recognize extraordinary service to the nation, is considered one of France's most prestigious awards. Bouchard was recognized for his contributions to the field of reproductive endocrinology, for his many years of teaching, and for the role that he has played in the advancement of health care.

Bouchard earned his medical degree at the Université Pierre et Marie Curie in Paris in 1978. His medical career began in Burkina Faso where he worked as a doctor while carrying out his military service. He was a research fellow at the Population Council's Center for Biomedical Research from 1978 to 1980 . Since 1989, he has been a member of the ICCR, a network of distinguished scientists and clinical investigators who conduct clinical trials to test the safety, efficacy, and acceptability of Councildeveloped reproductive health products. He is currently conducting research and teaching at the Hôpital Saint-Antoine in Paris.

\section{Matthew Hardy named co-editor-in-chief of the Journal of Andrology}

Matthew Hardy, senior scientist at the Population Council's Center for Biomedical Research, was recently appointed co-editor-in-chief of the Journal of Andrology. The bimonthly publication is the offi-

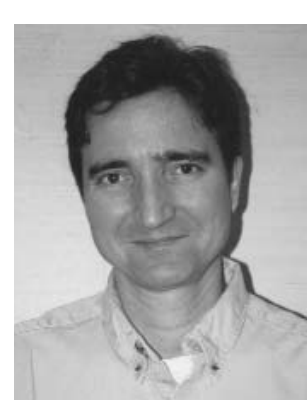
cial journal of the American Society of Andrology (ASA), a partnership of scientists and clinicians that promotes scientific interchange and knowledge of the male reproductive system.

The ASA, which fosters a multidisciplinary approach to the study of male reproduction, has more than 700 members all over the world. Their specialties include endocrinology, urology, animal science, anatomy, psychiatry, gynecology, and biochemistry. The association, based in Schaumburg, Illinois, was founded in 1975 .

The Journal of Andrology publishes new findings in the field of andrology. Of special interest to the journal are studies of male infertility, prostate diseases, and male sexual dysfunction. It also features articles on male contraception, regulation of spermatogenesis and sperm maturation, and gene expression and regulation in all tissues of the male reproductive system.

Hardy and Peter Schlegel, a Cornell urologist and former Population Council postdoctoral fellow, were selected as co-editors after submitting a proposal in response to the ASA's national search. The Council's Center for Biomedical Research was chosen as the journal's editorial office in part because of the strong reputation of its basic and clinical research in male reproduction.

Hardy's own studies focus on androgen secretion and male reproductive health, stress and reproduction, environmental toxicants and male fertility, and male contraception. Before joining the Council in 1991, Hardy was a postdoctoral fellow at Johns Hopkins University. His research has been published in several prominent journals, including Endocrinology, Molecular Endocrinology, and Biology of Reproduction, as well as the Journal of Andrology.

\section{John Bongaarts elected to National Academy of Sciences}

Demographer John Bongaarts, a Population Council vice president and director of its Policy Research

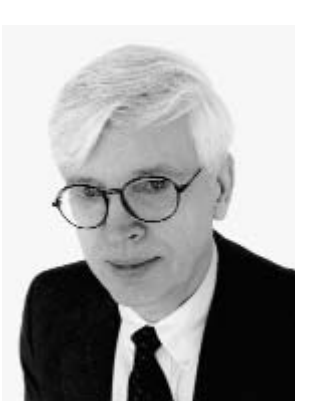
Division, was one of 72 new members elected this year to the U.S. National Academy of Sciences (NAS) in recognition of distinguished and continuing achievements in original research.

The election was held on April 30th during the

139th annual meeting of the NAS. Election to membership is considered one of the highest honors that can be accorded a U.S. scientist or engineer. Bongaarts joins an elite group of 1,907 active members.

On staff at the Population Council since 1973, Bongaarts conducts research on a range of population issues, including the determinants of fertility, population-environment relationships, the demographic impact of the AIDS epidemic, and population policy options in the developing world. One of the most respected and influential researchers in the field of demography, Bongaarts often is quoted in the scientific press and the mass media. His work has significantly advanced the field of population studies, providing a foundation of knowledge about demographic transitions and fertility behavior worldwide.

Bongaarts recently served as chairman of the Panel on Population Projections of the National Research Council of NAS. He also is a member of the Royal Dutch Academy of Sciences, a fellow of the American Association for the Advancement of Science, and a member of the Johns Hopkins Society of Scholars. His other awards include the Robert J. Lapham Award and the Mindel Sheps Award, both from the Population Association of America, and a Research Career Development Award from the National Institutes of Health. Bongaarts has a master's degree in systems analysis from the Eindhoven Institute of Technology, Netherlands, and a Ph.D. in physiology and biomedical engineering from the University of Illinois.

The National Academy of Sciences is a private organization of scientists and engineers dedicated to the furtherance of science and its use for the general welfare. It was established in 1863 by a Congressional Act of Incorporation, signed by Abraham Lincoln. The Act calls on the academy as an official adviser to the federal government, upon request, in any matter of science or technology. Additional information about the institution is available on the Internet at http://national-academies.org. 


\section{Council staff and fellows win key spots in IUSSP vote}

The ballots were counted-and many Population Council staff and fellows were elected. Of the new officers and 13 members voted to the governing council of the International Union for the Scientific Study of Population (IUSSP), two members are Population Council staffers and five others previously received fellowships or awards from the Population Council. John Casterline (PC/New York) and Zeba Sathar (PC/Islamabad, Pakistan) will each serve a three-year term on the governing board of this Paris-based organization. With approximately 2,000 members from 125 countries, the 74-year-old group is one of the most widely known and prestigious institutions in the field of population.

The new IUSSP vice president and president-elect, Hania Zlotnik, currently the chief of population estimates and projections at the Population Division of the United Nations, received a two-year Population Council fellowship in 1975 to pursue a doctorate at Princeton University. The IUSSP's roster of elected officials also includes Alaka

\section{USAID renews Population Council's Horizons program for five years}

The U.S. Agency for International Development (USAID) renewed funding for the Council's Horizons program, which conducts operations research to improve HIV/AIDS prevention, care, support, and treatment services in developing countries. The five-year renewal comes at a time when operations research — which examines operational and cost-effectiveness issues surrounding responses to the AIDS epidemic - is of critical importance. USAID and Horizons have been collaborating since 1997 to identify cutting-edge issues in HIV/AIDS service delivery. They work in more than 20 countries.

"We've learned a great deal about which behaviors place individuals at risk of HIV infection and what kinds
Basu of Cornell University's Division of Nutritional Sciences and a member of the Population Council's board of trustees, Alan Simmons of Canada's York University, and Zeng Yi of Duke University's Center for Demographic Studies, all of whom are former fellows of the Population Council. Additionally, in 1974 IUSSP council member James Trussell of Princeton University's Woodrow Wilson School of Public and International Affairs received the Council's Ritchie H. Reed Fellowship, an award given to promising scholars whose research combines demography and another of the social sciences.

John Casterline, senior associate in the Policy Research Division of the Council, has served on the Committee on Population of the U.S. National Research Council and on the Social Sciences and Population Study Section of the U.S. National Institutes of Health. Zeba Sathar, the country director for the Council in Pakistan, received the Council's Bernard Berelson Fellowship in 1992-1993 for midcareer training. of prevention and care approaches work, but we don't yet understand all the operational mechanisms needed to implement successful interventions," said Andrew Fisher, director of the Horizons program. "Operations research gives us the knowledge and tools to implement effective and affordable services in settings where resources are scarce."

Led by the Population Council, the Horizons partnership includes the International Center for Research on Women, the International HIV/AIDS Alliance, the Program for Appropriate Technology in Health, Tulane University, Family Health International, and Johns Hopkins University.

Momentum is a semi-annual newsletter of the Population Council. Information may be reproduced without permission, provided it is distributed free and the source is acknowledged.

Writer Melissa May Ruth Kalla Ungerer

Copyeditors Robert Heidel Suzie Elliott

Designers $\quad$ Y. Christina Tse Mike Vosika

$5 \cap$ Y E A R S

18 Population Council

One Dag Hammarskjold Plaza

New York, NY 10017

phone: 212-339-0500

fax: 212-755-6052

e-mail: pubinfo@popcouncil.org

http://www.popcouncil.org

\section{Council book explores improvements in reproductive health care}

The International Conference on Population and Development (ICPD), held in Cairo in 1994, marked a turning point in the history of the population field. Participants recognized the rights of all people to reproductive health and called for special attention to women's empowerment and a client-centered approach to reproductive health care.

The ICPD drew attention to the limitations of demographically driven family planning programs and outlined recommendations in general terms. However, directions for implementation were vague. Hoping to document the response to date, and to provide guidance to those grappling with how best to operationalize the ICPD reproductive health accords at the field level, Nicole Haberland, a Population Council program associate, and Diana Measham, a consultant to the Council, collaborated with colleagues from around the world to develop a series of detailed case studies about noteworthy programs.

In April, the Population Council published the results of their work, Responding to Cairo: Case Studies of Changing Practice in Reproductive Health and Family Planning. The book brings together case studies from 18 developing countries that provide concrete examples of successful programs that have been carried out since the 1994 conference.

The case studies draw on material from more than 20 programs and projects in Africa, Asia, and Latin America. A careful analysis of the processes involved in implementing commitments made at Cairo, the book provides examples others can follow. Confronting issues as varied as the contraceptive target system in India, gender-based violence in Latin America, and sexuality counseling in Egypt, the authors depict a gradual shift in perceptions, policies, and programs since the Cairo conference.

Reflecting some of the main themes of ICPD, part one examines efforts to promote client-centered care in India, China, and South Africa, countries where previous, longstanding national policies led to clear violations of some women's reproductive rights. Part two takes a detailed look at efforts to reorient service providers toward a more client-centered service delivery. Parts three and four profile programs that broaden the content of reproductive health care to include such neglected issues as sexuality, gender, and partner relations. Finally, part five takes the reader beyond the realm of service provision by examining community-based efforts to empower women and combat violence against women and girls.

Nicole Haberland has worked for the Council since 1996, managing programs on married adolescents, power in sexual relations, and social development. She holds a master's degree in public health from Columbia University. Diana Measham, who has worked with the Council—first as staff, now as a consultant—since 1993, holds a master's degree in health planning and financing from the London School of Economics and the London School of Hygiene and Tropical Medicine and is a doctoral candidate in reproductive epidemiology at the University of California, Berkeley.

For more information, visit www.popcouncil.org/ cairocasestudies/index.html.

\section{REGIONAL OFFICES}

South and East Asia

New Delhi, India

West Asia and North Africa

Cairo, Egypt

Sub-Saharan Africa

Accra, Ghana

Latin America and the Caribbean Mexico City, Mexico

The Population Council is an international, nonprofit, nongovernmental organization that seeks to improve the well-being and reproductive health of current and future generations around the world and to help achieve a humane, equitable, and sustainable balance between people and resources. The Council conducts biomedical, social science, and public health research and helps build research capacities in developing countries. Established in 1952, the Council is governed by an international board of trustees. Its New York headquarters supports a global network of regional and country offices.

\section{ISSN 1535-0525}

() 2002 The Population Council, Inc. Printed in the USA on recycled paper

Photo credits. All photos courtesy of staff photographer Karen Tweedy-Holmes and Melissa May, except on the following pages: Meclissa May, except on the following pages: page 4 (top), Mathare Youth Sports Association page 4 (bottom), Stephanie Berger; page 5 , Stephanie Berger; page 6, photo courtesy of
Her Royal Highness Basma bint Talal of Jordan. 


\section{IIJNMOJ NOIIVIndOd BHI WOy= SMBN}

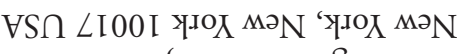

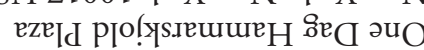
punos uomplndod

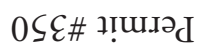

LO 'иәиен мәN

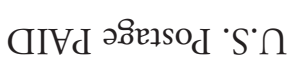

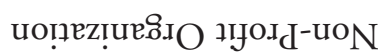

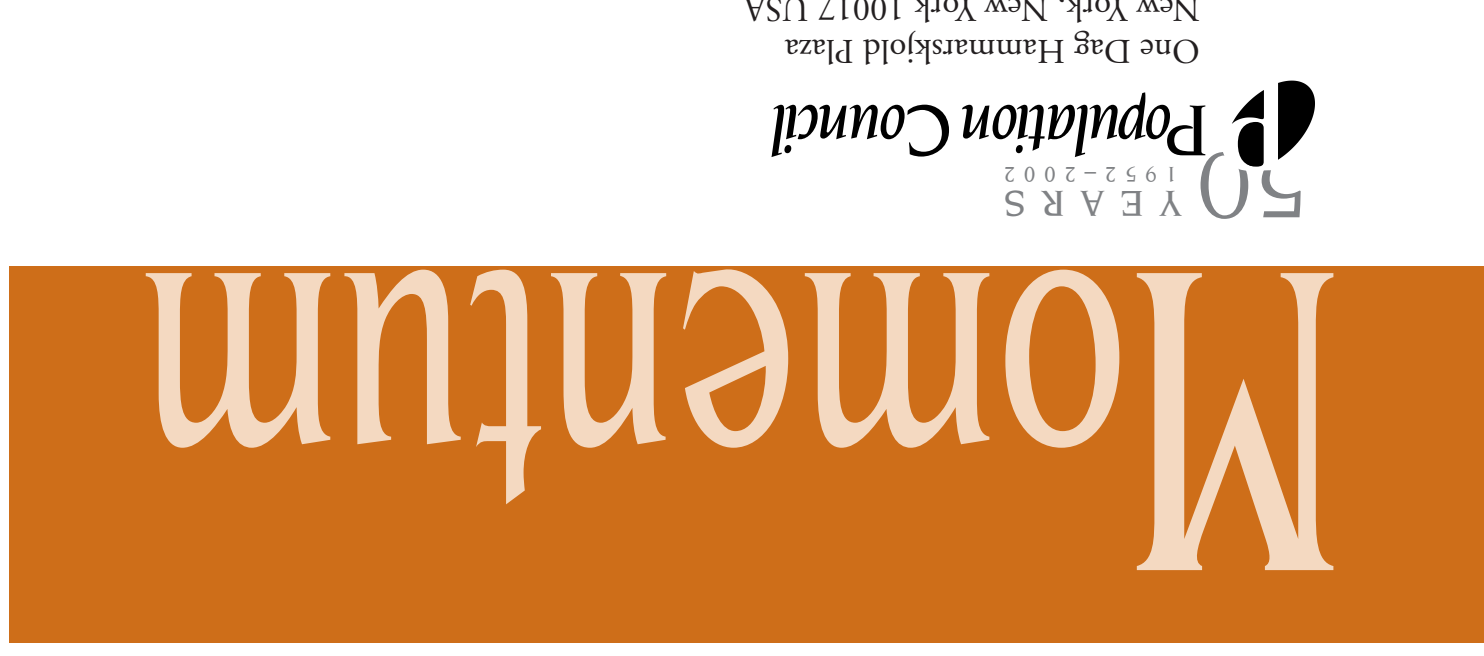

\section{Developing health policies for the elderly in Asia}

The better-educated your children, the greater your chances for a healthy old age — at least if you live in Taiwan—according to a recent study by Zachary Zimmer, a Population Council research associate whose work examines the health and well-being of older adults in developing countries.

Zimmer, the principal investigator on a grant from the National Institute on Aging (NIA), and Population Council president Linda Martin, a co-investigator on the project, are exploring changes in and determinants of health among older adults in a number of Asian countries. Zimmer said that the "graying" of a population is no longer an issue facing only the United States and Europe. Declining fertility and mortality in many Asian countries are reshaping demographic profiles in the region to such a

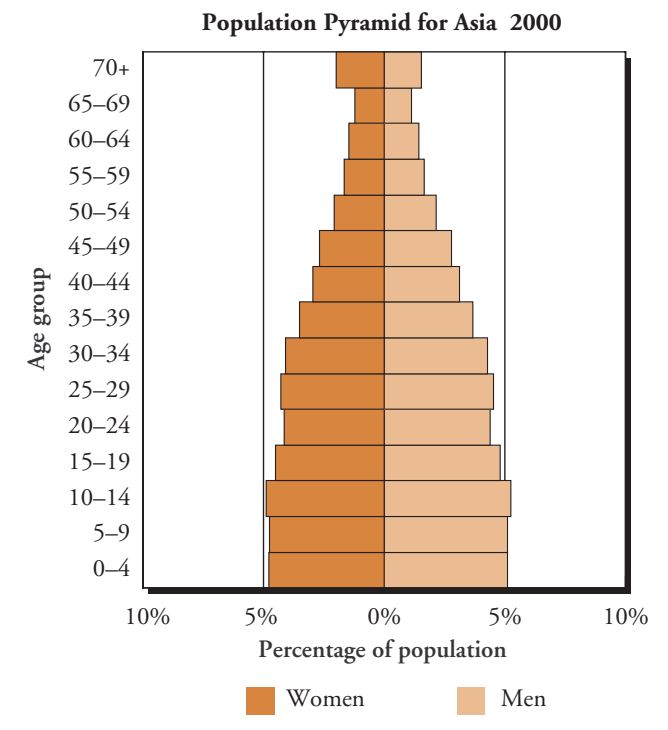

degree that the population pyramid is losing its familiar form. The pyramid's base, which represents the proportion of the population at young ages, is shrinking, while the 70-year-plus group at the pyramid's peak is expanding. A comparison of two graphs representing population pyramids for Asia, one for 2000 and another based on projections for 2040, shows the gradual widening of the top of the "pyramid" that will occur in the next few decades.
The NIA-funded study focuses on Taiwan, Singapore, the Philippines, Indonesia, and China. Zimmer notes that China's one-child policy will bring many new and unexpected challenges associated with an aging population. "Family sizes declined in a single generation from seven or eight children per family to just one, and the cohort of children from the 1950s is now in its 40s and 50s," he said. "In the past, parents could have counted on several children to care for them in their

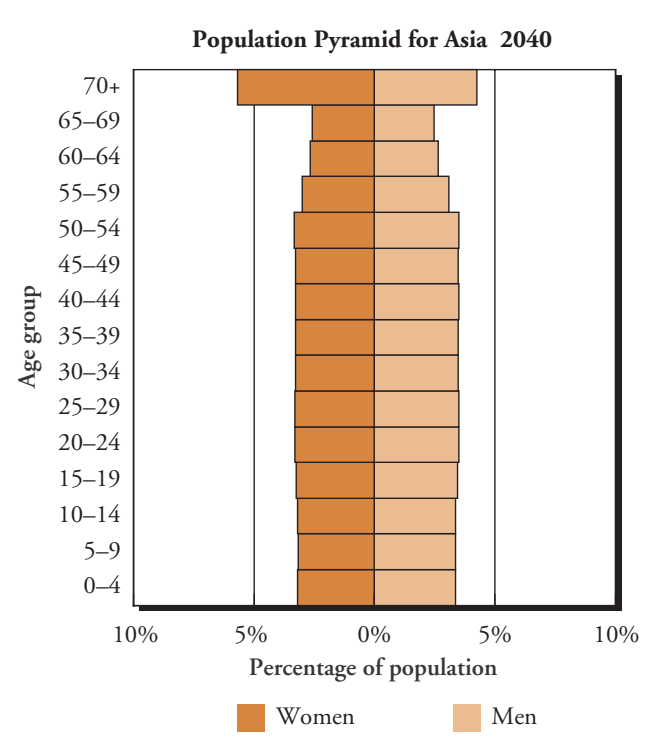
old age, but now there is often just one. When they retire, what policies and health resources will be there for them?"

At this point, no one can predict the sort of experiences the elderly will face when there are fewer children to care for them than in previous generations. Findings from the study in Taiwan, however, showed that high education levels of children are a positive factor in an

elderly parent's health status. In Taiwan, and probably in other societies where multigenerational households are the norm, the study found that children who can negotiate the health care system, supervise medication, and watch over the nutrition of their parents contribute to the good health of the aged. By identifying such determinants of well-being, researchers hope to play a part in encouraging the adoption of policies that will assist the growing proportion of the elderly in societies across Asia. 